\title{
Fiscal Policy Perspective on Virtual Business During COVID-19 and Its Challenges: The Case of Indonesia
}

\author{
Prianto Budi Saptono*, Cyntia Ayudia** \\ *Faculty of Administrative Sciences, Universitas Indonesia \\ ${ }^{* *}$ Tax Researcher at Pratama-Kreston Tax Research Institute \\ DOI: 10.29322/IJSRP.11.01.2021.p10987 \\ http://dx.doi.org/10.29322/IJSRP.11.01.2021.p10987
}

\begin{abstract}
This study has two objectives. The first aim is to examine tax policies on virtual businesses in Indonesia. Government Regulation in Lieu of Law Number 1 of 2020, promulgated into Law Number 2 of 2020, regulates taxation policies on trade through electronic systems. This law is an integral part of the regulations regarding the handling of the COVID-19 pandemic. The second objective is to analyze the potential challenges that arise in tax policy implementation on virtual businesses. This study is qualitative research with data collection techniques in the form of documentation and literature studies. The research concludes that the implementation of VAT on PMSE does not violate the consensus or legal character of VAT in concept. However, the imposition of income tax and electronic transaction tax still creates polemics due to conflicts with the tax treaty provisions. Furthermore, the Government's biggest challenge is the courage to set taxes on digital companies over the top, considering that Indonesia has bargaining power. Besides, the Indonesian Government needs to maximize big data analysis and Automatic Exchange of Information (AEoI) to overcome the possibility of fraud.
\end{abstract}

Index Terms- fiscal policy, virtual business, COVID-19

\section{INTRODUCTION}

Since the Indonesian President Joko Widodo announced the first two confirmed cases of the novel coronavirus (COVID-19) infection in Indonesia on March 2, 2020, the spread of COVID-19 has continued to increase (World Health Organization, 2020a, p. 1). The World Health Organization (WHO) declared COVID-19 as a global pandemic on March 11 (p. 1). The Indonesian Government has implemented various strategies and preventive policies to tackle pandemic issues (Djalante, 2020). Those policies mainly aim to minimize COVID-19 risk spreading through human-to-human transmission (World Health Organization, 2020b), including the LargeScale Social Restrictions (Pembatasan Sosial Berskala Besar/PSBB) policy in almost all regions of Indonesia. During the crisis, movement restrictions have implications for inhibiting community, service industries, and labor-intensive manufacturing (Balwin \& Mauro, 2020, p. 5).

As well as profound implications for people's health, COVID-19 is significantly impacting businesses and the economy. Brands across the globe are worrying about how COVID-19 will impact businesses as a whole. Electronic commerce (e-commerce), business-tobusiness (B2B), business-to-consumer (B2C), and traditional (brick-and-mortar) brands alike are all bracing for the impact of COVID19 on business (Davis \& Toney, 2020). Demand has fallen for certain conventional services with direct interaction, such as tourism services. Mass layoffs and closures had already occurred, and many businesses are financially fragile (Bartik, 2020). However, on the other hand, the digital sector achieves windfall gain during the pandemic.

The COVID-19 outbreak has led to a significant change in business conditions. According to Deloitte Report (2020, p. 1), the pandemic is rapidly changing consumers' daily habits, consumption patterns, and ways of thinking toward online channels. World Trade Organization (2020, p. 1) has reported that in response to the COVID-19 pandemic, the enforcement of social distancing, lockdowns, and other measures has led consumers to increase online shopping, usage of social media, internet telephony, and teleconferencing, as well as streaming of videos or films. The increase in B2C sales is particularly evident in online demand for multiple categories, including entertainment, medical supplies, household essentials, and food products, using innovative non-contact formats (Deloitte, 2020, p. 1). These shifts are likely to stick to last until post-pandemic.

The COVID-19 pandemic has an impact and threatens economic growth for Indonesia due to global economic uncertainty. To recover and strengthen the national economy, the Indonesian Government issues Government Regulation in Lieu of Law No. 1 of 2020 regulates 4 (four) taxation policies as an extraordinary measure. First, the income tax rate reduction for resident corporate taxpayers (Wajib Pajak Dalam Negeri/WPDN) and permanent establishment (Bentuk Usaha Tetap/BUT), namely 22\% for 2020-2021 fiscal year and 20\% starting in 2022 fiscal year. Second, the tax treatment of Trade through Electronic Systems (Perdagangan Melalui Sistem 
Elektronik/PMSE). Third, the time extension to implement the right and to fulfill tax obligations. Fourth, the granting of authority to the Finance Minister in providing customs facilities in exemption or relief of import duties to address emergencies situation.

In principle, the tax treatment policy of PMSE is a unilateral step considering that there is still no global consensus on digital economy taxation. This study will discuss the following issues: (1) Fiscal policy perspective on virtual business, including providing tax incentives to entities and imposing VAT for digital businesses; (2) challenges in implementing fiscal policy.

\section{CONCEPTUAL FRAMEWORK}

\section{A. Virtual Business in a Digital Economy}

A digital economy is a convergence of communications, computing, and information. The new economy's essential shifts a structural from the industrial economy toward an economy characterized by information, intangibles, services, and a parallel change toward new work organizations and institutional forms (Sharma, 2006). One of the essential elements of the digital economy is digitalization and the intensive use of information and communication technologies. Since performing commercial activities over a new technology platform, business activities can operate virtually and do not require any particular facilities.

Susan Ward (2020) has defined virtual business is any business that conducts all or most of its business via the internet and telecommunications, which focuses on its digital capabilities to achieve the desired business goals. It may or may not have some physical presence — such as an office or warehouse - but there is not a physical location that customers can visit. Virtual business is the complete opposite of traditional bricks-and-mortar business, relying heavily on face-to-face transactions with customers, a physical workspace, and physical records and data (Sage, 2020). The office is a state of mind - as long as people have the gear and get an internet connection and make phone calls so that people can work in a virtual office (Campbell, 2017). With low overhead costs, little investment requirements, and low startup costs, business owners worldwide consider a virtual business for the present and the future (Lorette, n.d.).

With the development of virtual business in a digital economy environment, the growth of electronic commerce (e-commerce) has already improved business value by fundamentally changing the ways products are conceived, marketed, delivered, and supported. Concerning the nature of the item traded on e-commerce, the standard definition falls into two main categories-first, distance selling, which refers to the electronic selling of tangible goods, but still must be physically delivered using traditional channels. Second, digital content services or direct e-commerce concerns online ordering, payment, and intangible goods supplies.

\section{B. Taxes Covered in Tax Treaty}

The term "Taxes Covered" as stipulated in Article 2 of the OECD Model Tax Convention has explained what types of taxes that includes in a Tax Treaty. The OECD Model covers taxes on income and capital. The OECD Model provides a general definition of taxes on income as all taxes imposed on total income or elements of income, including taxes on gains from the alienation of movable or immovable property and taxes on the total amounts of wages salaries paid by enterprises. Meanwhile, the general definition of taxes on capital includes all taxes imposed on total capital or capital elements, including taxes on capital appreciation (Lang, 2013).

Furthermore, the provisions of Article 2 paragraph 4 tax treaty explain that the type of tax also applies to any taxes that arise as long as they are identical or substantially similar to income tax and if the tax is an addition or substitute ("in addition" or "in place of") income tax. The OECD Model and most of the Double Taxation Conventions contain a clause according to which the treaty shall apply to identical or substantially similar taxes. The tax imposition is after the signing date in addition to, or in place of, the existing taxes. These clauses seek to prevent situations in which new taxes' introduction leads to a DTC's renegotiation. If the newly introduced taxes are comparable to the existing tax at the time of the agreement's designation, the treaty is applicable (Lang, 2013).

Based on this understanding, the taxes covered include entirely new taxes, but the new taxes must not conflict with the applicable tax treaty provisions. If the tax is to replace the existing tax, there is a risk to be covered in the tax treaty agreement (Brandstetter, 2011, p. 64). Thus, a source country has the right to impose a type of tax other than income tax as regulated in the tax treaty.

\section{Level Playing Field on Neutrality Principle}

Neutrality calls for the impartiality of treatment. The partiality concern may arise from: (1) unequal treatment of essentially similar taxpayers; or (2) the same treatment of essentially different taxpayers (Groves, 1948, p. 18). The tax neutrality principle is a tax system not influencing the taxpayers' business decisions. The baseline to decide whether a taxation system is neutral compares with the situation as no-tax levied (Chen, 2018).

To overcome tax distortions and develop the tax system in the digital economy era, the OECD suggests that the design of tax policies must comply with a well-known principle: "neutrality" and "fairness." According to OECD Report (2015, pp. 17, 20), the neutrality principle in taxation on the digital economy should seek to be neutral and equitable for all forms of business activity, between conventional and electronic forms of commerce. Taxpayers in similar situations carrying out similar transactions should be subject to similar levels of taxation.

With the principle of neutrality, the tax system will increase state income and minimize tax discrimination for each economic choice (OECD, 2015a, p. 30). According to Musgrave \& Musgrave (1989, p. 218) and Bird \& Wilkie (2013, p. 293), the principle of fairness is the essential or critical criterion for designing a suitable tax structure. The principle of equality or fairness is the most widely known and contains how to distribute the tax burden as evenly as possible (Oestreicher \& Spengel, 2007, p. 3). 


\section{Nexus Rules and Significant Economic Presence}

The emergence of the digital economy presents challenges in taxation, such as determining the basis imposition (nexus) of a jurisdiction's economic presence. According to Plekhanova (2017), nexus rules are a broad category of state's sourcing rules. From the income tax perspective, a nexus rule defines the circumstances when an economic connection between a particular item of income and sufficient for a particular state to tax this income item.

Traditionally, a structure of a nexus rule has a geographical or a functional dimension. Nexus with the geographical dimension can be statutory or treaty. Theoretically, the basis for determining this nexus type is on either a physical presence standard or an economic presence standard, usually geographical. This standard requires that the factors connecting business profits of an economic actor with a state (or, in the case of a dependent agent) must have a physical location within that state's territory. Domestic laws and treaties of most countries require some physical presence either directly or through an agent for a country to assert taxing jurisdiction over a non-resident company's business profits. A proven means of applying income taxation based on significant economic presence is the "factor presence nexus," adopted by the US Multistate Tax Commission (MTC) as a model statute for states on October 17, 2002 (Gianni, 2018, p. 270).

The significant economic presence proposal in a jurisdiction arises when a non-resident enterprise has a significant economic presence based on the factor that evidences a purposeful and sustained interaction with the jurisdiction via digital technology and other automated tools. These factors would be combined with a factor based on the revenue derived from digital transactions into the country to ensure that only significant economic presence cases are covered, limit the taxpayers' compliance costs, and provide certainty for cross-border activities. The following sections describe the details of such an option, together with potential approaches for attributing income to the new nexus (OECD, 2015, p. 107; Abrahamson, 2020).

\section{RESEARCH METHOD}

This research is a qualitative method utilized to provide a better understanding in answering research questions regarding the fiscal policy perspective on virtual business during COVID-19 in Indonesia. According to Cresswell (2012), qualitative research has the characteristic of exploring a problem and developing a detailed understanding of a central phenomenon of social or human problems. The research method is conducting a literature review of relevant journals and articles. By using qualitative methods, there are six stages to conclude the results (Bryman, 2016). It begins with determining research questions, finding relevant subjects, collecting and interpreting evidence, conceptual framework, writing the finding, and conclusion.

\section{RESULT AND DISCUSSION}

\section{A. Fiscal Policy on Virtual Business During COVID-19 in Indonesia}

COVID-19 pandemic has implications for a slowdown in national economic growth, a decline in state revenues, an increase in state spending and financing, and a deterioration in the financial system as indicated by a decline in various domestic economic activities. However, from another perspective, a crisis creates opportunities for business actors to act and changes. Opportunities arise along with changes in consumers' daily habits through the use of digital-based services.

Reporting from Indonesia's Ministry of Communication and Informatics (2019), the growth in the value of e-commerce in Indonesia reached $78 \%$ in 2018. Meanwhile, according to the results of research conducted by Google, Temasek, and Bain \& Company, the value of e-commerce market capitalization in Indonesia based on the Gross Merchandise Value (GMV) method reaches US\$ 21 billion or around IDR 294 trillion (Citradi, 2019). During the pandemic, sales via e-commerce platforms increased by $26 \%$ from the monthly average for the second quarter of 2019, which was US\$2.4 billion or IDR 36 trillion GMV in April 2020. Additionally, the volume of demand increased 5-10 times during the COVID-19 pandemic.

According to the theory of change is a practical and essential part of a successful transformation effort (Organizational Research Services, 2004, p. 1). Companies must be bold and ambitious that embrace new realities, and take timely action to capture market share and emerge after the crisis as market leaders. The action takes courage to reinvent new business models amid a pandemic and invest in times of high uncertainty.

Deputy Director of the OECD's Center for Tax Policy and Administration, Grace Perez-Navarro, as quoted by Tax Notes (2020) states a pandemic should be the right momentum and time to consider new fiscal policy strategy, specifically taxes. According to PerezNavarro, learning from past experiences, many countries find it easier to introduce new tax types in tax reform. Governments should consider such measures to ensure progressivity in their tax systems. Tax policy options that governments could consider better administration of VAT systems. Countries could improve enforcement to tackle VAT fraud and look at better VAT mechanisms on digital trade.

The urgency of digital sector taxation is driven by increasing economic activity via electronics. As electronic commerce (e-commerce) continues to overgrow, it could significantly affect the social and economic structures. E-commerce has a substantial impact on taxation and tax policy. Concerns have expressed that e-commerce could result in the erosion of tax bases because it allows transactions to customers in Indonesia without a physical presence in economic activity.

Amid the digital-based business development, the Indonesian Government has responded with a tax extensification policy of Trade through Electronic Systems (Perdagangan Melalui Sistem Elektronik/PMSE) to recover and strengthen the national economy in a pandemic situation. The tax treatment of PMSE has regulated in Government Regulation in Lieu of Law Number 1 of 2020 , subsequently 
ratified as Law No. 2 of 2020, in junction with Finance Minister Regulation No. 48/PMK.03/2020 ("PMK-48") as an implementing regulation. PMSE regulations in Law No. 2 of 2020 include the provisions of Value Added Tax (Pajak Pertambahan Nilai/PPN), income tax (Pajak Penghasilan/PPh), and electronic transaction tax (Pajak Transaksi Elektronik/PTE).

First, VAT on intangible or digital taxable goods and taxable services within the customs and excises territory originating from outside the customs area through electronic trading systems. With the enactment of PMSE regulation, digital products such as music and film streaming subscriptions, digital applications and games, and online services from abroad or domestic business actors will be in the same treatment as various conventional products that have been subject to VAT.

Alan A. Tait (1988, pp. 4-6) defines the basic concept of Value Added Tax (VAT), "So the value-added can be looked at from the additive side (wages plus profits) or the subtractive side (output minus inputs)." The good VAT, in essence, achieved through three design norms that require the VAT be levied on a broad consumption base at a single rate, collected incrementally through all stages of the production and distribution chain through the invoice-credit method, and imposed on a destination basis (James, 2015). This method is an "indirect" way to assess the tax on value-added. Under the indirect method, all outputs and inputs are VAT objects.

In principle, VAT is an indirect tax levied on consumption so that the end consumer bears the tax burden. Therefore, business actors who conduct business activities in the PMSE sector only collect, deposit, and report VAT. These business actors, including foreign traders, foreign service providers, trade through electronic systems organizers (Penyelenggara Perdagangan Melalui Sistem Elektronik/PPMSE) both foreign (non-resident) and domestic determined by the Minister of Finance. PPMSE is a provider of electronic communication tools used for trade transactions.

There are currently 46 companies appointed as PMSE businesses, including Amazon, Google, Netflix, and Spotify, which the majority came from the United States. Based on Digital Economy Report from UNCTAD (2019, p. 2), China and the United States dominate $70 \%$ of the world's largest digital platforms and market capitalization value up to $90 \%$. Indonesia is one of the market countries for this digital business.

In essence, VAT on PMSE is not a new thing. Before the issuance of the PMSE provisions, the Indonesian Government had regulated VAT on the utilization of taxable intangible goods and taxable services from outside the customs and excises territory area. The provisions contained in the Finance Minister Regulation No. 40/ PMK.03/2020 ("PMK-40"). The regulation stipulates that individuals or entities, both taxpayers and taxpayers, can make VAT deposits. However, this regulation does not yet recognize the term digital goods and services. The accentuation in PMK-48 determines the over-the-top digital business actors to become VAT collectors.

According to PMK-48, there are two characteristics of e-commerce business actors appointed as taxpayers to collect VAT. First, the value of digital product sales transactions to buyers in Indonesia exceeds IDR 600 million in one year or IDR 50 million in one month within 12 (twelve) months. Second, has the number of traffic or access in Indonesia exceeding 12,000 in one year or 1,000 in one month. The VAT rate is $10 \%$ of the tax base. Based on the criteria, a VAT collector's appointment is based solely on the amount of transaction value with buyers in Indonesia or the amount of traffic (accessors) from Indonesia regardless of the business actors' domicile or jurisdiction.

More specifically, PMSE PPN collectors make proof of collection in the form of invoices, order receipts, or similar documents that state VAT collection and have made payments. PMSE VAT collectors must deposit VAT for each tax period no later than the following month after the tax period ends. Depositing VAT uses the billing code with the tax account code 411219 and the deposit type code 111. Deposits of collected VAT can use Rupiah (Exchange Rate of the Minister of Finance), United States Dollar, or other foreign currency stipulated by the DGT. If the US dollar deposit occurs abroad, the payment is made through correspondent banks by wire transfer by including the billing code and SWIFT Code as a reference.

Almost all countries that implement the VAT system as a form of consumption tax, using the destination principle as a principle of VAT collection. Based on this principle, the imposition of VAT on goods and services only applies to places where consumption of these goods and services occurs (places of consumption). The several reasons for strong preference of a consumption base over an income base because (i) consumption is a fairer and more reliable measure of welfare than income; (ii) consumption taxes are simpler to administer because they do not rely on complex realization and timing rules; (iii) consumption taxes has its relative neutrality concerning: savings and investment decisions, and consumption decisions (the exclusion of savings means that no penalty for choosing to consume now or later); (iv) the neutrality of consumption taxes leaves decisions must be in accordance to market conditions, and this should enhance investment, efficiency, and economic growth.

PMSE VAT collection provision on consumption upon supplies of digital goods and digital services performed by individuals or entities as buyers who meet the following criteria: (i) residing or domiciled rank in Indonesia based on the location of the correspondence address or country selection during registration on the PMSE VAT site or system is Indonesia; (ii) make payments using debit facilities, credit, or other payment facilities provided by institutions in Indonesia; (iii) transact using an internet protocol in Indonesia or using a telephone number with an Indonesian country code.

In line with the objective connecting factor, linking taxation right of a country based on the existence of related economic activities in the territory of a country so that the Government has the legitimacy of imposing VAT on PMSE though organizer located abroad the customs and excises territory (Darussalam \& Septriadi, 2017).

Furthermore, the extensification of digital tax objects in PMK-48 aims to create a level playing field between conventional and digital businesses. VAT regulation was previously only imposed on conventional transactions. Through PMK-48, intangible taxable goods and 
services are also subject to VAT. In line with the general legal character, where the VAT imposition applies to all personal expenses, there is no discrimination between goods and services. (Rosdiana \& Irianto, 2014). The VAT imposition on domestic or foreign PMSE organizers shows no discrimination for PMSE organizers based on region (neutrality principle). Therefore, fiscal policy must seek to create equality and protecting all stakeholders (Basu, 2002).

The VAT mechanism also has various advantages during this pandemic, including fiscal, psychological, and economic benefits. First, the invoice system makes it easier for tax authorities to supervise and minimize the cost of compliance from the fiscal aspect. Second, taxpayers are also not psychologically conscious when making payments so that consumers will not significantly be affected. Third, from an economic perspective, this type of tax is neutral towards a person's choice of saving or consumption, in line with the Government's goal of increasing consumption during a pandemic — a logical consequence of psychological benefits.

Second, income tax (PPh) on PMSE activities carried out by non-resident tax subjects (foreign traders or service providers). Those business actors are firmed based on the nexus for a significant economic presence, and the treatment is the same as for a permanent establishment. According to the OECD Report (2015, p. 107), a significant economic presence in a jurisdiction arises when a nonresident enterprise has a significant economic presence based on factors that evidence a purposeful and sustained interaction with that country's economy via digital technology and other automated tools. Underlying these factors is the revenue generated from digital transactions into the country to ensure that only significant economic presence cases are covered and provide certainty for cross-border activities. Based on Law No. 2 of 2020, a significant economic presence needs to meet the following requirements: (a) consolidated gross turnover of business groups up to a certain amount; (b) sales in Indonesia up to a certain amount; (c) up to a certain number of active digital media users in Indonesia.

Third, electronic transaction tax (PTE) which is a new type of tax. However, due to the tax treaty's implementation, the determination of PPMSE taxpayers, foreign traders, and foreign service providers as Permanent Establishment is not valid. In that case, as long as it has met a significant economic presence, it will be subject to PTE.

Furthermore, Director General of Tax Regulation No. 07/P.J./2020 ("PER-07") has stipulated PPMSE taxpayers, foreign traders, and foreign service providers register as taxpayers in Permanent Establishment \& Expatriate Tax Offices. The regulation was released to provide legal certainty, ease of administration, and enhance the supervision of the implementation of taxpayers' rights and the fulfillment of taxpayers' obligations for PMSE business actors.

\section{B. Challenges in Fiscal Policy Implementation on Virtual Business}

The implementation of a policy is inseparable from challenges. This study describes at least four challenges to be a concern in implementing tax policies on virtual businesses in Indonesia. In a digital economy era, another challenge in applying fiscal policy to virtual business is can wider social changes and lead to new shadow economy activities (OECD, 2017, p. 3). Shadow economy is related to consumer to consumer (C2C) transactions because of the difficulty in tracking or tracking transaction information data.

Article 5 of PMK-48 identifies buyers, either individuals or entities, with the domicile criteria for correspondence and registration in Indonesia, payment through Indonesian institutions, and a protocol address in Indonesia. However, this can be an opening for buyers to avoid their tax obligations using a Virtual Private Network (VPN). This tax avoidance effort can lead to a loss of potential state revenue. Moreover, research results from Geosurf (2018) show that Indonesia and India are in the first rank of most VPN users in the world, with $38 \%$ of the world's total users.

Another fiscal challenge is the imposition of income tax on top companies. This policy has generated polemics regarding the determination of a permanent establishment (Bentuk Usaha Tetap/BUT), which clashed with the tax treaty provisions. The formulation of PE is also inseparable from the provisions in the tax treaty with jurisdictional partner countries.

Article 2 paragraph 5 of Law No. 36 of 2008 ("PPh Law") in junction with Finance Minister Regulation No. 35/PMK.03/2019 ("PMK35") regulates provisions regarding the determination of PE in Indonesia. Based on Article 4 PMK-35, a permanent establishment must meet the cumulative criteria, namely (a) the existence of a place of business in Indonesia; (b) the place of business is permanent, and (c) the place of business is used to carry on business or carry out activities. The types of PEs that apply in Indonesia are limited to assets types, activity types, agency type, and insurance type. Besides, referring to Article 5 OECD Model Tax Convention defines a permanent establishment as "for this convention, the term "PE" means a fixed place of business through which the business of an enterprise is wholly or partly carried on." The term "PE" including a place of management, a branch, or an office.

According to domestic tax regulations and the OECD Model Tax Convention, to be designated as a PE requires physical presence. These regulations have not regulated a PE or a business profit clause that adopts a digital business concept or a significant economic presence. Therefore, income tax on PMSE only applies to resident non-treaty partners. In contrast, the tax treaty does not allow the imposition of income tax on income received or obtained from Indonesia by resident treaty partners. The tax treaty is a lex specialis derogat legi generali to domestic regulations.

Lex specialis derogat legi generali means that more specific rules will prevail over (abrogates, overrules, trumps) more general rules. One test that is applied in circumstances when (i) both customary and treaty sources of law exist, and (ii) these two sources cannot be construed consistently. If the implementation of domestic tax provisions eliminates the tax treaty, it can lead to treaty override. Treaty override is the most violent manifestation of the lack of international law effectiveness, which means a lack of legal protection for economic operators and taxpayers acting globally (Pietro, 2015). 
The difficulty in renegotiating tax treaties is because it requires a long process and time. Additionally, 69 (sixty-nine) tax treaties between Indonesia and partner countries regulate PE criteria to date. Thus various countries in the world have implemented unilateral measures for taxation of electronic transactions, including Indonesia. Determination of unilateral steps, considering that there is no global consensus on tax rights distribution and the allocation of global operating profits from digital economic transactions. The absence of a global consensus has resulted in a tax on PMSE in Indonesia as a source country. This policy is an alternative temporary solution to obtain justice in tax rights distribution with foreign business actors' significant economic presence in the jurisdiction.

In line with the imposition of an income tax on PMSE business actors that is not possible due to a constraint on PE status as regulated in the tax treaty, the Indonesian Government has established anticipatory steps. The electronic transaction tax (Pajak Transaksi Elektronik/PTE) regulation reflects these anticipatory steps. Based on Article 6 paragraph 8 Law No. 2 of 2020, suppose the PMSE business actors is a resident from the tax treaty partner countries and cannot enforce PE stipulations due to implementing a tax treaty. In that case, as long as it has met a significant economic presence, it will be subject to PTE.

The emergence of electronic transaction tax would remove Indonesia's regulation barrier as a source of income in the taxing digital transactions conducted by foreign and domestic business actors. However, it becomes an interesting discussion regarding the sovereignty of the PTE and income tax (Pajak Penghasilan/PPh) position in the law, namely whether PTE is a new tax type. In principle, an electronic transaction tax enactment is an effort to tax income earned through electronic systems and originating from Indonesia. The basis of PTE's imposition is the sale of digital goods and services overseas through an electronic system to buyers or users in Indonesia carried out by foreign traders or foreign service providers, either directly or in PPMSE.

In this case, it is crucial to understand whether the term "Taxes Covered" in tax treaty provisions also includes PTE. If it includes, then PTE cannot be applied. On the other hand, if it is not taxes covered in the tax treaty, then PTE can be applied without being bound by the terms of "Taxes Covered." Article 2 of the OECD Model Tax Convention has explained what types of taxes regulate on a tax treaty, including the application to taxes on income and capital. Furthermore, the provisions of Article 2 paragraph 4 tax treaty explain that the type of tax also applies to any taxes that arise as long as they are identical or substantially similar to income tax and if the tax is an addition or substitute ("in addition" or "in place of") income tax.

Based on this understanding, the taxes covered include entirely new taxes, but the new taxes must not conflict with the applicable tax treaty provisions. If the tax is to replace the existing tax, there is a risk to be covered in the tax treaty agreement (Brandstetter, 2011, p. 64). Thus, a source country has the right to impose a type of tax other than income tax as regulated in the tax treaty.

If reviewing international base practice regarding digital taxes, many other countries have implemented unilateral policies, such as France and other European Union countries with Digital Services Tax, Equalisation Levy in India, and Diverted Profit Tax in United Kingdom (UK). In India, the equalization levy is a hybrid withholding tax with characteristics that blur the lines between direct and indirect tax. The measure requires Indian businesses to buy advertising services from foreign companies to withhold a $6 \%$ tax and remit the Government's charge, except foreign companies with a permanent establishment (PE) in India (White, 2020).

A proposed digital services tax accompanied the directive's draft regarding the creation of a "significant digital presence" as an additional anchor for the allocation of revenues on revenues generated from providing certain digital services. Regarding its design, the characteristic of the EU digital services tax (EU DST) is a "hybrid tax" that embodies elements of an income tax and a consumption tax (Geringer, 2020). The tax base is the gross amount of the transaction.

UK has implemented Diverted Profit Tax (DPT) since 2015 (KPMG, 2016, p. 1). The DPT rules provide UK taxation rights on income from electronic transactions within their jurisdiction because they fulfill a taxable presence. This provision addresses issues for persons carrying on the UK's activity connected with the supply of goods, services, or other property by a foreign company with a UK-taxable presence (a permanent establishment). It allows entities or transactions that lack economic substance to exploit tax mismatches and evade UK taxes, implying a significant reduction in total tax arising from UK activities.

UK believes that the DPT is not an income tax. The DPT is a new tax with a tax imposition mechanism in the form of rates, tax structures, tax bases, and tax compliance procedures, which is different from Income Tax. However, the DPT tax base mostly follows a profit attribution method similar to Income Tax. However, the UK has issued detailed technical and operational provisions for implementing DPT, including provisions regarding DPT imposition in income tax through the tax credit mechanism. Thus, although there are still conflicts regarding the DPT regulations because they are considered "tax covered" in the Tax Treaty, the DPT also regulates the application to avoid the emergence of double taxation.

Until the writing of this research, the Indonesian Government had not yet established derivative regulations that further detail the imposition of income tax and electronic transaction tax on PMSE. So, what steps should the Indonesian Government take related to PTE? The OECD has the multilateral instrument (MLI), which is a tool designed to incorporate base erosion and profit shifting (BEPS) measures into tax treaties (Dueñas \& Bunn, 2019). Accordingly, without formally amending each bilateral treaty, a new multilateral instrument would modify all bilateral treaties' overlapping provisions. Indeed, there have been many situations in which States have adopted a multilateral convention to introduce common international rules and standards and thereby harmonize a network of bilateral treaties, for example, in the area of extradition (OECD, 2014). The MLI in BEPS Action Plan 15 aims to avoid a lengthy and timeconsuming tax treaty renegotiation process. However, the Multilateral Instrument (MLI) text and its Explanatory Statement were developed through a negotiation involving more than 100 countries and are still in the approval process.

This publication is licensed under Creative Commons Attribution CC BY.

http://dx.doi.org/10.29322/IJSRP.11.01.2021.p10987

WwW.ijsrp.org 
Indonesia faces the challenge of enforcing electronic transaction tax sovereignty, considering the significant potential revenue from the digital economy that increases significantly amid the pandemic. However, the consequence of implementing PTE as a unilateral policy may result in a greater risk of multiple payments or international double taxation from cross-border transactions. These consequences inevitably lead to inconvenience between taxpayers and tax authorities. Furthermore, the imposition of electronic transaction taxes can threaten exports and lead to trade war conflicts.

Thus, the electronic transaction tax application depends on how courageous the Indonesian Government is in facing international threats or sanctions. In terms of data, based on Internet World Stats (2020), Indonesia is in the fourth position of internet users globally in 2020, after China, India, and the United States. This potential can be a bargaining power for Indonesia. Besides, learning from international base practice, electronic transaction tax can be made into a hybrid scheme with the tax base is the transaction's gross amount. Thus, the concept of an electronic transaction tax is excluded from the income tax realm and is not a tax scope covered by the tax treaty.

Besides the challenges regarding the content and terminology of taxes on digital business, there are also challenges related to tax administration. Throughout the world, tax administrations face the formidable task of protecting their revenue base without hindering either the development of new technologies or the business community's involvement in the evolving and growing e-marketplace. It concerns the Government's center of e-commerce on state and local revenue (Jones \& Basu, 2002).

In facilitating the exchange of information between countries, the OECD initiated the Multilateral Competent Authority Agreement on Automatic Exchange of Financial Account Information (MCAA) in the Automatic Exchange of Information framework. It aims to avoid fraud in financial reporting. Each taxing authority can perform data tracing for tax purposes, such as implementing PMSE VAT policies relating to other countries to avoid fraud.

However, it also has to note that politically, the US is aggressively investigating the unilateral implementation of digital taxes. It poses a challenge for tax authorities in implementing the PPN PMSE policy because it will be difficult to trace information related to VAT collecting entities' transactions.

\section{CONCLUSION}

The COVID-19 pandemic situation prompted the Indonesian Government to implement policies and take extraordinary steps to minimize the national economic slowdown impact on society and business activities. This condition also changes the tax function paradigm, from a budgetary function (budgetary) to a regulatory function. Through Law Number 2 of 2020, the Government stipulates regulations regarding the imposition of taxes on Trade Through Electronic Systems (PMSE), including Value Added Tax, Income Tax, and Electronic Transaction Tax. The implementation of VAT on PMSE does not violate the consensus or legal character of VAT in concept. However, the imposition of income tax and electronic transaction tax still creates polemics due to conflicts with the tax treaty provisions. When referring to international best practices, many countries have implemented the hybrid concept in imposing digital taxes. Thus, the Government's biggest challenge is the courage to set taxes on digital companies over the top, considering that Indonesia has bargaining power. Furthermore, the Indonesian Government needs to maximize big data analysis and the Automatic Exchange of Information (AEOI) to overcome the possibility of fraud.

\section{REFERENCES}

[1] Abrahamson, J. (2020). International Taxation of Banking. Kluwer Law International BV.

[2] Balwin, R., \& Mauro, B. W. (2020). Mitigating the COVID Economic Crisis: Act Fast and Do Whatever It Takes. London: CEPR Press.

[3] Bartik, A. W. (2020). The Impact of COVID-19 on Small Business Outcomes and Expectation. PNAS. Retrieved from https://www.pnas.org/content/pnas/117/30/17656.full.pdf

[4] Basu, S. (2002). European VAT on Digital Sales. Journal of Information, Law, and Technology.

[5] Bird, R. M., \& Wilkie, J. S. (2013). Designing Tax Policy: Constraints and Objectives in an Open Economy. eJournal of Tax Research, 11(3), 284-320.

[6] Brandstetter, P. (2011). "Taxes Covered": A Study of Article 2 of the OECD Model Tax Conventions. Amsterdam: IBFD.

[7] Bryman, A. (2016). Social Research Methods (5th ed.). Oxford: Oxford University Press.

[8] Campbell, A. (2017, November 1). New Growth Trend: Businesses that Serve Virtual Businesses. Retrieved from Small Business Trends: https://smallbiztrends.com/2006/10/new-growth-trend-businesses-that-serve-virtual-businesses.html

[9] Chen, S.-C. J. (2018). Neutrality as Tax Justice: The Case of Common Consolidated Corporate Tax Base under the EU Law. Tax Policy Conference (pp. 3366). Harvard University.

[10] Citradi, T. (2019, 12 23). E-Commerce RI Tumbuh Pesat, Tapi Kalah Dari China \& Singapura. Retrieved from CNBC Indonesia https://www.cnbcindonesia.com/tech/20191223152017-37-125264/e-commerce-ri-tumbuh-pesat-tapi-kalah-dari-china-singapura

[11] Creswell, J. W. (2012). Educational Research: Planning, Conducting and Evaluating Quantitative and Qualitative Research (4th ed.). Boston: Pearson Education.

[12] Davis, S., \& Toney, L. (2020, September 23). How Coronavirus (COVID-19) Is Impacting Ecommerce [September 2020]. Retrieved from ROI Revolution: https://www.roirevolution.com/blog/2020/10/coronavirus-and-ecommerce/

[13] Deloitte. (2020). COVID-19 Will Permanently Change E-Commerce in Denmark. Retrieved from https://www2.deloitte.com/content/dam/Deloitte/dk/Documents/strategy/e-commerce-COVID-19-onepage.pdf

[14] Djalante, R. (2020). Review and Analysis of Current Responses to COVID-19 in Indonesia: Period January to March 2020.

[15] Dueñas, S., \& Bunn, D. (2019). The Challenges of Consensus in the Digital Economy on the International Tax Treaty System. Tax Foundation. Retrieved from https://taxfoundation.org/digital-economy-international-tax-treaty-system/

[16] GeoSurf. (2018). VPN Usage Statistics. Retrieved from GeoSurf: https://www.geosurf.com/blog/vpn-usage-statistics/

[17] Geringer, S. (2020). National Digital Taxes - Lessons from Europe. South African Journal of Accounting Research. 
[18] Gianni, M. (2018). OECD BEPS (In)Action 1: Factor Presence as a Solution to Tax Issues of the Digital Economy. The Tax Lawyer, 72(1), 255-298. Retrieved from https://search.proquest.com/docview/2202112393?accountid=17242

[19] Groves, H. M. (1948). Neutrality in Taxation. National Tax Journal, Vol. 1, No. 1, 18-24. Retrieved from https://www.jstor.org/stable/41789749

[20] Internet World Stats. (2020). Top 20 Countries With the Highest Number of Internet Users. Retrieved from Internet World Stats: https://www.internetworldstats.com/top20.htm

[21] James, K. (2015). Cambridge Tax Law Series: The Rise of the Value-Added Tax. New York: Cambridge University Press.

[22] Johnston, S. S. (2020, September 14). AEOI May Pave Way for More Capital Taxation, OECD Official Says. Retrieved from Tax Notes.

[23] Jones, R., \& Basu, S. (2002). Taxation of Electronic Commerce: A Developing Problem. International Review of Law Computers \& Technology, Vol. 16, No. 1, 35-52. doi:10.1080/13600860220136093

[24] Kementerian Komunikasi dan Informasi. (2019, 2 28). Kemkominfo: Pertumbuhan e-Commerce Indonesia Capai 78 Persen. Retrieved from Kementerian Komunikasi dan Informasi: https://kominfo.go.id/content/detail/16770/kemkominfo-pertumbuhan-e-commerce-indonesia-capai-78persen/0/sorotan_media\#: :text=Kemkominfo\%3A\%20Pertumbuhan\%20e\%2DCommerce\%20Indonesia\%20Capai\%2078\%20Persen,Kategori\%20Sorotan\%20Media\&text=Skalanews\%20\%2D\%20

[25] KPMG. (2016, January). Diverted Profits Tax. Updated HMRC Guidance. United Kingdom: KPMG.

[26] Lang, M. (2013). Introduction to the Law of Double Taxation Conventions (2nd edition). IBFD.

[27] Lorette, K. (n.d.). How to Run a Virtual Business. Retrieved from Small Business Chron: https://smallbusiness.chron.com/run-virtual-business-2143.html

[28] Musgrave, R. A., \& Musgrave, P. B. (1989). Public Finance in Theory and Practice (5th ed.). McGraw-Hill.

[29] OECD. (2014). Developing a Multilateral Instrument to Modify Bilateral Tax Treaties. OECD Publishing.

[30] OECD. (2015). Addressing the Tax Challenges of the Digital Economy, Action 1 - 2015 Final Report. Paris: OECD Publishing.

[31] OECD. (2017). Shining Light on The Shadow Economy: Opportunities and Threats. OECD.

[32] Oestreicher, A., \& Spengel, C. (2007). Tax Harmonisation in Europe: The Determination of Corporate Taxable Income in the EU Member States. Working Paper. ZEW - Leibniz Centre for European Economic Research.

[33] Organizational Research Services. (2004). Theory of Change: A Practical Tool For Action, Results, and Learning. Annie E. Casey Foundation.

[34] Pietro, C. d. (2015). Tax Treaty Override and the Need for Coordination between Legal System: Safeguarding the Effectiveness of International Law. World Tax Journal.

[35] Plekhanova, V. (2017). Global Matchmakers: Tax Challenges and Responses in the Digital Economy. New Zealand: University of Auckland.

[36] Sage. (2020). Building a Virtual Business: Your Guide to a New Way of Working. Johannesburg.

[37] Sharma, S. K. (2006). E-Commerce in a Digital Economy. IGI Global.

[38] Tait, A. A. (1988). Value Added Tax: International Practice and Problems. Washington, DC: International Monetary Fund.

[39] UNCTAD. (2019). Digital Economy Report 2019: Value Creation and Capture: Implications for Developing Countries. United Nations.

[40] Ward, S. (2020, July 28). What Is a Virtual Business? Retrieved from The Balance Small Business: https://www.thebalancesmb.com/a-definition-of-virtualbusiness-2948416

[41] White, J. (2020). Domestic Businesses Take The Hit From India's Equalisation Tax. International Tax Review.

[42] World Health Organization. (2020a). Coronavirus Disease 2019 (COVID-19) Situation Report - 1. World Health Organization, Indonesia. Retrieved from https://www.who.int/docs/default-source/searo/indonesia/Covid-19/who-indonesia-situation-report-1.pdf?sfvrsn=6be5b359_0

[43] World Health Organization. (2020b, February 2). Preparedness Actions Taken on Novel Coronavirus in Indonesia. Retrieved from World Health Organization South-East Asia, Indonesia: https://www.who.int/indonesia/news/detail/05-02-2020-preparedness-actions-taken-on-novel-coronavirus-inindonesia

[44] World Trade Organization. (2020). E-Commerce, Trade, and The COVID-19 Pandemic. Retrieved from https://www.wto.org/english/tratop_e/Covid19_e/ecommerce_report_e.pdf

\section{AUTHORS}

First Author - Dr. Prianto Budi Saptono, Lecturer, Universitas Indonesia, prianto.budi@gmail.com Second Author - Cyntia Ayudia, Researcher, Pratama-Kreston Tax Research Institute, cyntia.ayudia@gmail.com

Correspondence Author - Prianto Budi Saptono, prianto.budi@gmail.com, +6281190618 